\title{
Germination of five Indonesian brown rice: evaluation of antioxidant, bioactive compounds, fatty acids and pasting properties
}

\author{
Hadi MUNARKO ${ }^{1,2}$, Azis Boing SITANGGANG ${ }^{1 \star}$ (D) , Feri KUSNANDAR ${ }^{1}$, Slamet BUDIJANTO ${ }^{1}$
}

\begin{abstract}
Germination can alter the physicochemical, nutritional, and nutraceutical value of brown rice. This study aimed to evaluate some characteristic changes from five Indonesian brown rice varieties during germination. The germination was carried out through a complete soaking method for up to $120 \mathrm{~h}$, and the samples were taken and analyzed every $24 \mathrm{~h}$. The results showed that germination increased GABA ( $\gamma$-aminobutyric acid) content in brown rice. The highest level of GABA, up to $126.55 \mathrm{mg} / 100 \mathrm{~g}$, obtained in rice var. Inpari 43, after $120 \mathrm{~h}$. Germination also affected the changes in phenolic content, antioxidant capacity, and $\gamma$-oryzanol, while fatty acid compositions showed no changes. The pasting properties changed significantly after germination, especially in peak viscosity, final viscosity, breakdown, and setback. In conclusion, the changes in brown rice characteristics during germination, especially for increased GABA content and shifting of pasting properties, are valuable information for developing functional rice-based food products.
\end{abstract}

Keywords: antioxidant; GABA; germinated brown rice; $\gamma$-oryzanol; phenolic content; pasting profiles.

Practical Application: Germinated brown rice from some Indonesian brown rice varieties can potentially be used to enriched rice-based food products with GABA.

\section{Introduction}

Rice is becoming one of the grain crops cultivated and consumed by the majority of people worldwide, especially in Asia and Africa region. It approximately contributes to half of the world population as a source of carbohydrate (Gong et al., 2017). Rice is considered a strategic commodity in Indonesia, not only as of the most primary food crop that cultivated by farmers but also as a staple food for about 240 million Indonesian people (Munarko et al., 2020).

Nowadays, increasing awareness to consume whole food as a healthy food has increased. Consuming whole food in regular diets has been associated with the reduced risk of chronic diseases, including cardiovascular disease, obesity, type II diabetes, and cancer (Gong et al., 2017). Brown rice or unpolished rice is considered as whole food because only the inedible outer layer part of the paddy is removed, while the bran layer still intact to the endosperm. A number of studies have shown that brown rice contains a high amount of antioxidant activity and bioactive compounds, including phenolic compounds, $\gamma$-oryzanol, and unsaturated fatty acid (Cáceres et al., 2017; Jayadeep \& Malleshi, 2011; Munarko et al., 2020). However, the existence of a bran layer in brown rice affects consumer preferences, especially on its harder texture, poor cooking, and eating quality (Munarko et al., 2019; Xia et al., 2017).

Germination process is able to improve the texture and taste of brown rice (Cho \& Lim, 2016). During germination, many hydrolytic enzymes such as $\alpha$-amylase, $\beta$-amylase, and protease are activated. They hydrolyzed starch and protein resulted in an increase of oligosaccharides, sugars, and amino acids (Mohan et al., 2010). These changes also affected the physical characteristics, including its pasting properties of germinated brown rice (GBR) (Xu et al., 2012). Besides, germination also enhanced bioactive compounds such as $\gamma$-aminobutyric acid (GABA) (Cáceres et al., 2017; Ohtsubo et al., 2005; Zhang et al., 2014). GABA, a nonprotein amino acid, play important role as neurotransmitter in the brain and has some essential physiological functions such as antihypertensive and anti-stress effects on human health (Cáceres et al., 2017; Tiansawang et al., 2016; Watchararparpaiboon et al., 2010).

There have some germination methods being applied to produce GBR with the purpose of enhancing the accumulation of GABA in brown rice (Thitinunsomboon et al., 2013). In summary, the germination process may apply in two different procedures, i.e., a simple soaking method by steeping of the seeds in water, and temporary immersion followed by atmospheric germination (Cho \& Lim, 2016). The simple soaking method is the easiest procedure to produce GBR compared to the atmospheric germination. This method is suitably applied at the low production scale (individual or household scale), and in the areas where people easily access brown rice to produce GBR. In Indonesia, rice is commonly cultivated at local farmlands to cover their daily consumption. 
Therefore, it is easy to produce GBR at the household scale by applying the simple soaking method.

In Indonesia, more than one hundred rice varieties have been released in the last two decades to fulfill the farmers needed. Several varieties, such as Inpari 42, Inpari 43, Situ Bagendit, IPB $3 S$, and Inpari 17 are potentially high-yield varieties that have been developed. Inpari 42 and Inpari 43 are lowland irrigated rice cultivars that have low amylose content. Situ Bagendit and IPB 3 S are intermediate amylose content varieties and is commonly cultivated by farmers in dryland and paddy fields, respectively. Var. Inpari 17 is categorized as high amylose rice and cultivated in lowland (Munarko et al., 2020). Although many studies have reported the effect of germination on chemicals and bioactive compounds in many varieties over the world (Kaur et al., 2017; Kiing et al., 2009; Ohtsubo et al., 2005; Zhang et al., 2014), little is known especially for Indonesian rice varieties. Thus, this study aimed to evaluate some physicochemical and functional changes of five Indonesian brown rice varieties during germination.

\section{Materials and methods}

\subsection{Materials}

Four rice varieties (Inpari 42, Inpari 43, Situ Bagendit, and Inpari 17) were obtained from Indonesian Center for Rice Research (Subang, Indonesia), while IPB 3 S variety was obtained from Seed Center, IPB University (Bogor, Indonesia). These rice varieties are certified paddy seeds. Ethanol, methanol, chloroform, 2-propanol, phenol, sodium hydroxide, folin-ciocalteu's phenol reagent, 2,2-Diphenyl-1-picrylhydrazyl (DPPH), gallic acid, ascorbic acid, $\gamma$-oryzanol, and $\mathrm{BF}_{3}$-methanol were purchased from Merck (Darmstadt, Germany). Fatty acid methyl esters C8-C22 (CRM 18920) and BHT were from Sigma Aldrich (USA). Boric acid was purchased from Kanto Chemical Co. Inc. (Tokyo, Japan). $\gamma$-aminobutyric acid (GABA) was from Acros Organics (New Jersey, US). Other chemical reagents used were analytical grade.

\subsection{Brown rice preparation}

Brown rice samples were prepared by the hulling process (Yanmar, Japan). The whole kernels were separated from broken rice using rice grader (Ogawa Seiki.Co.Ltd, Japan) and followed by manual sortation. Brown rice samples were vacuum sealed and stored at $4{ }^{\circ} \mathrm{C}$ for the further germination process.

\subsection{Germination procedure}

Germination procedure of brown rice applied by full soaking method. Brown rice was sanitized using $0.1 \%$ sodium hypochlorite solution for 30 minutes and followed by rinsing in tap water. The sample was taken as $0 \mathrm{~h}$ treatment (ungerminated). The production of GBR was performed by soaking the sanitized brown rice in water $(1: 10, \mathrm{w} / \mathrm{v})$ and incubated it in hot air sterilizer to maintain the water temperature at $33 \pm 2{ }^{\circ} \mathrm{C}$. The soaking water was removed and changed every four hours. The samples were removed after $24,48,72,96$, and $120 \mathrm{~h}$ and washed by using tap water before dried into a freeze dryer
(Labconco, US). The dried GBR was ground using a blender (Miyako, Indonesia), sieved, vacuum sealed, and stored at $-20{ }^{\circ} \mathrm{C}$ before analysis.

\subsection{Evaluation of GABA content}

GABA content was analyzed duplicate according to the method of Zhang et al. (2014) with a slight modification in sample preparation. Sample ( $1.0 \mathrm{~g})$ was placed in a plastic tube, and $5 \mathrm{~mL}$ deionized water was added. The mixture was then extracted for an hour, followed by a centrifugation at $3000 \mathrm{rpm}$ (Eppendorf 5810R) for 30 minutes and filtered. A half milliliter of supernatant was added with $0.2 \mathrm{~mL}$ borate buffer $(\mathrm{pH} 9), 1.0 \mathrm{~mL}$ phenol reagent $6 \%(\mathrm{w} / \mathrm{v})$, and $0.4 \mathrm{~mL}$ sodium hypochlorite $9 \%$ and then mixed vigorously. The tube was then boiled in the water bath for 10 minutes and cooled immediately in ice water for 20 minutes to develop a blue color. The absorbance was measured by a UV-Vis spectrophotometer (Thermo Scientific 150, US) at $645 \mathrm{~nm}$. Standard curve calibration of GABA was prepared to determine GABA concentration in the samples and expressed as $\mathrm{mg} \mathrm{GABA} / 100 \mathrm{~g}$ dried samples.

\subsection{Determination of total phenolic content and antioxidant capacity}

Phenolic compounds were extracted using ethanol extraction (Munarko et al., 2020). The rice flour (approximately $1.5 \mathrm{~g}$ ) was extracted with $20 \mathrm{~mL}$ of ethanol $80 \%(\mathrm{v} / \mathrm{v})$ using a shaker (Innova2300, new Brunswick scientific) for 30 minutes and centrifuged at $6000 \mathrm{rpm}$ (Hermle Z $383 \mathrm{~K}$, Wehingen, Germany) at $4{ }^{\circ} \mathrm{C}$ for 30 minutes. The supernatant was collected into a dark bottle and stored at $4{ }^{\circ} \mathrm{C}$.

Total phenolic content (TPC) was analyzed duplicate by the modified Folin-Ciocalteu's method. Extract $(0.2 \mathrm{~mL})$ was mixed with $1.8 \mathrm{~mL}$ of $10 \times$ diluted Folin-Ciocalteau reagent (freshly prepared) and $1.8 \mathrm{~mL}$ of $\mathrm{Na}_{2} \mathrm{CO}_{3} 60 \mathrm{~g} / \mathrm{L}$. After reacting for 90 minutes, the mixture was analyzed by a UV-Vis spectrophotometer (Thermo Scientific 150, US) at $725 \mathrm{~nm}$. The absorbance was compared to the standard curve of gallic acid and expressed as $\mathrm{mg}$ gallic acid equivalent per $100 \mathrm{~g}$ dry samples (mg GAE/100 g) (Munarko et al., 2020).

Antioxidant capacity was measured by DPPH scavenging activity (Brand-Williams et al., 1995) with slight modification. The phenolic extract of rice $(0.3 \mathrm{~mL})$ and $0.7 \mathrm{~mL}$ of distilled water were mixed with $3.0 \mathrm{~mL}$ of freshly DPPH solution $120 \mu \mathrm{M}$ and incubated in the darkroom for 60 minutes. The mixture was then analyzed using a UV-Vis spectrophotometer (Thermo Scientific 150, US) at $515 \mathrm{~nm}$. The antioxidant activity was expressed by $\mathrm{mg}$ ascorbic acid equivalent per $100 \mathrm{~g}$ of dried sample (mg AAE/100 g).

\subsection{Analysis of $\gamma$-oryzanol}

Analysis of $\gamma$-oryzanol applied a partial extraction method (Lilitchan et al., 2008). Two identical rice flour samples (1.0 g) were extracted with isopropanol using different volumes $(4 \mathrm{~mL}$ and $8 \mathrm{~mL}$ ) and centrifuged for 10 minutes at $2500 \mathrm{rpm}$ (Eppendorf 
5810R). The absorbance of the supernatant was measured using a UV-Vis spectrophotometer (Thermo Scientific 150, US) at $326 \mathrm{~nm}$. Total $\gamma$-oryzanol of the sample was compared to the $\gamma$-oryzanol standard curve and then calculated as follows (Equation 1):

$$
y=\frac{x_{1} x_{2}}{2 x_{1}-x_{2}}
$$

where $y$ is the concentration of $\gamma$-oryzanol in the rice samples (expressed as $\mathrm{mg} / 100 \mathrm{~g}$ dry sample), $x_{1}$ is the concentration of $\gamma$-oryzanol in $4 \mathrm{~mL}$ extract, and $x_{2}$ is the concentration of $\gamma$-oryzanol in $8 \mathrm{~mL}$ extract.

\subsection{Analysis of fatty acid composition}

Lipid extraction applied the method of Bligh \& Dyer (1959) which modified by Munarko et al. (2020). Sample (5.0 g) was mixed with distilled water, chloroform, and methanol to reach chloroform:methanol:water became 1:2:0.8 (v/v/v), followed by centrifugation at $4000 \mathrm{rpm}$ (Hermle Z $383 \mathrm{~K}$, Wehingen, Germany) for 10 minutes. The sample was added chloroform and water containing $0.85 \%$ of $\mathrm{KCl}$ to reach the final ratio of 2:2:1.8 of chloroform:methanol:water $(\mathrm{v} / \mathrm{v} / \mathrm{v})$. The mixture was centrifuged at $4000 \mathrm{rpm}$ (Hermle Z $383 \mathrm{~K}$, Wehingen, Germany) for 10 minutes and then filtered to remove the solid. The supernatant was allowed to separate into two phases. The lower chloroform phase was collected and evaporated using nitrogen gas at $50{ }^{\circ} \mathrm{C}$.

Fatty acid derivatization was prepared by using the $\mathrm{BF}_{3}$ methanol catalyst, and the analysis of fatty acid composition was assayed by Gas Chromatography 7890A (Agilent Technologies, California, US) with a flame ionization detector (FID). The column was DB-23 (J and W Scientific, Folsom, CA) with a dimension of $60 \mathrm{~m} \times 0.25 \mathrm{~mm}$, film thickness of $0.25 \mu \mathrm{m}$. The temperature of the detector and injector was set at $280{ }^{\circ} \mathrm{C}$ and $270{ }^{\circ} \mathrm{C}$, respectively. The initial temperature was set at $130^{\circ} \mathrm{C}$ and held for $2 \mathrm{~min}$. It increased to $170{ }^{\circ} \mathrm{C}$ at a rate of $6.5^{\circ} \mathrm{C} / \mathrm{min}$ and held for $5 \mathrm{~min}$. Then, it increased to $215^{\circ} \mathrm{C}$ at $2.75^{\circ} \mathrm{C} / \mathrm{min}$ and held for $12 \mathrm{~min}$, followed by increased to $230^{\circ} \mathrm{C}$ at $30{ }^{\circ} \mathrm{C} / \mathrm{min}$ and held for $30 \mathrm{~min}$. Helium and nitrogen from ultra-high purity grade at flow rate 11.07 and $31.24 \mathrm{~mL} / \mathrm{min}$, respectively, were used as carrier gasses. Identification of fatty acid composition was determined by comparing the retention time of each peak in the sample containing internal standard (C17:0) with the respective external standard (C8:0 to $\mathrm{C} 22: 0)$ containing internal standard of fatty acid methyl esters (Taufik et al., 2016).

\subsection{Analysis of pasting profile}

Pasting profiles of brown rice flour were carried out duplicate by using a rapid visco analyzer (RVA) (Tec-Master, Newport Scientific, Australia). Sample (3.0 g, moisture content 14\%) was diluted in $25 \mathrm{~g}$ of distilled water, followed by heating and cooling cycle with constant stirring. The sample was heated at $50{ }^{\circ} \mathrm{C}$ for $1 \mathrm{~min}$ in advance of heating to $95^{\circ} \mathrm{C}$ at $6{ }^{\circ} \mathrm{C} / \mathrm{min}$ and maintained for $5 \mathrm{~min}$. The temperature reduced to $50{ }^{\circ} \mathrm{C}$ at $6{ }^{\circ} \mathrm{C} /$ min and then held at $50{ }^{\circ} \mathrm{C}$ for $5 \mathrm{~min}$.

\subsection{Statistical analysis}

Analysis of the variance and significance of the differences among the samples were conducted by analysis of variance (ANOVA) procedure and Duncan's multiple range test of SPSS software version 22 .

\section{Results and discussion}

\subsection{The effect of germination on GABA content}

The changes in GABA content during germination are presented in Figure 1. GABA contents in ungerminated brown rice are ranging from $19-27 \mathrm{mg} / 100 \mathrm{~g}$. These contents significantly changed during germination. The accumulation of GABA in GBR var. Inpari 42, Inpari 43, and IPB 3S increased slightly after soaked for $24 \mathrm{~h}$, while others were not changed. During the long period of the soaking time, these compounds tend to increased consistently until the end of soaking time. The highest GABA content was observed after soaking at $120 \mathrm{~h}$ in var. Inpari 43 (126.55 mg/100 g), which increased up to 4.7 times higher than that in ungerminated brown rice. GABA content in GBR var. IPB 3S, Situ Bagendit, Inpari 42, and Inpari 17 also raised up to $98.80 \mathrm{mg} / 100 \mathrm{~g}, 88.23 \mathrm{mg} / 100 \mathrm{~g}$, $81.66 \mathrm{mg} / 100 \mathrm{~g}$, and $75.37 \mathrm{mg} / 100 \mathrm{~g}$, respectively, after germinating for $120 \mathrm{~h}$.

The increase of GABA content during germination was reported in seeds and legumes, including in brown rice (Mohan et al., 2010; Tiansawang et al., 2016; Zhang et al., 2014). Accumulation of GABA was closely related to the activation of some enzymes that converts glutamate to succinate via GABA, called GABA shunt, which converts L-glutamic acid into GABA by glutamate decarboxylase enzyme (GAD). GABA was then metabolized to succinic semialdehyde and succinate by GABA transaminase (GABA-T) and succinic semialdehyde dehydrogenase (SSADH) (Shelp et al., 1999). Our study showed that germination was able to increase the GABA content in all varieties. The results were comparable to that of brown rice which also germinated by the

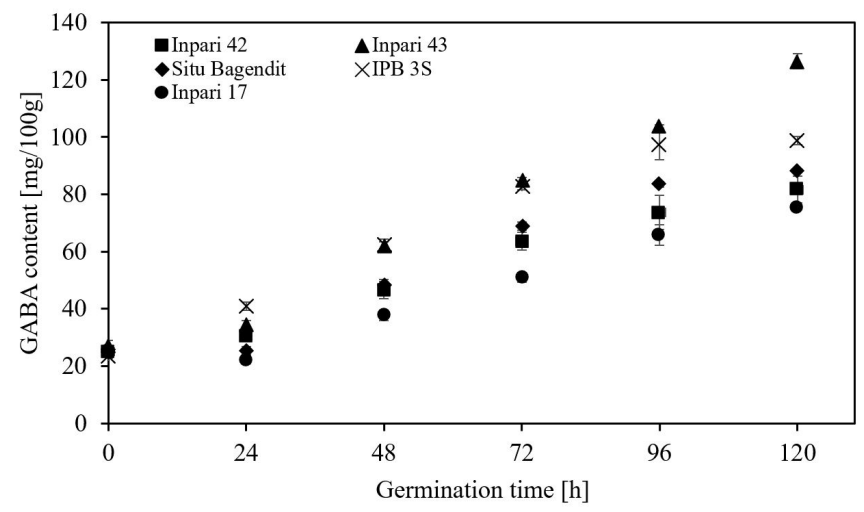

Figure 1. GABA profiles of germinated brown rice from five Indonesian rice varieties at different steeping times. 
simple soaking method. GABA content in GBR var. KDML 105 and CNT 1 increased up to $73.05 \mathrm{mg} / 100 \mathrm{~g}$ and $92.42 \mathrm{mg} / 100 \mathrm{~g}$ after soaking for $72 \mathrm{~h}$ (Kaosa-ard \& Songsermpong, 2012). The accumulation of GABA in GBR var. Koshihikari also increased up to $149.03 \mathrm{mg} / 100 \mathrm{~g}$ after germination for $96 \mathrm{~h}$ (Ohtsubo et al., 2005).

GABA content in GBR varied among rice varieties. These results are in-line with previous studies in several varieties from different geographical regions. GABA content in GBR var. Indica Guichao was reported higher than in var. Japonica Jing 305 (Zhang et al., 2014). Four Ecuadorian sprouted brown rice showed significant differences after soaking and incubating at designed conditions (Cáceres et al., 2014). GBR from ten cultivars in India also exhibited significantly different among the samples (Kaur et al., 2017).

\subsection{The effect of germination on total phenolic content and antioxidant capacity}

Figure 2 shows TPC and antioxidant capacity of five Indonesian brown rice during germination. Germination of brown rice affected the TPC and antioxidant capacity. After $24 \mathrm{~h}$ steeping time, both TPC and antioxidant capacity of five germinated brown rice decreased significantly. The results are agreed with the results in brown rice Indica SLF09 and some different grains after soak for $24 \mathrm{~h}$ and $6 \mathrm{~h}$, respectively (Cáceres et al., 2017; Tiansawang et al., 2016). During the soaking process and changing the soaking water, some phenolic compounds might leach out to the water soaking. It might affect the reduction of phenolic content and antioxidant capacity in GBR.

After soaking of 48 to $120 \mathrm{~h}$, five varieties showed different trends in TPC and antioxidant capacity. In var. Inpari 42, antioxidant capacity showed no significant changes for the longer steeping time, and slightly changed in TPC. However, the amount of TPC and antioxidant capacity in all periods of germination time was lower than that in ungerminated brown rice. Brown rice var. Inpari 43, Situ Bagendit, IPB 3S, and Inpari 17 represented similar trends after the soaking process. Both of antioxidant capacity, as well as TPC, were increasing after soaked at 48 to $96 \mathrm{~h}$ compared to that of $24 \mathrm{~h}$. Our results are agreed with three different varieties during germination (Phattayakorn et al., 2016). The TPC of red non-waxy rice (red Jasmine) variety decreased significantly, although the DPPH scavenging activity did not change after germination. In contrast, black waxy rice and white non-waxy rice (KDML105) increased both of total phenolic content and the antioxidant activity. From this study, it is important to pay attention that brown rice varieties have important contribution in term of enhancing TPC and antioxidants in GBR. In addition, technological properties applied in the germination process might affect the accumulation of TPC and antioxidant activity in GBR.

\subsection{The effect of germination on $\gamma$-oryzanol content}

The $\gamma$-oryzanol is a bioactive compound in the lipophilic fraction that be the major substance found in brown rice. It consists of ten or more compounds with ester bonds between ferulic acid and triterpenes (Cho \& Lim, 2016). $\gamma$-oryzanol content in brown rice during germination is shown in Table 1. During germination by simple soaking method, $\gamma$-oryzanol underwent a slightly changes either in increasing or decreasing at the certain soaking time. The content of $\gamma$-oryzanol in var. Inpari 42, IPB 3S, and Inpari 17 did not change significantly after soaking for $24 \mathrm{~h}$, whereas that in var. Situ Bagendit and Inpari 43 showed a slight decreasing and increasing, respectively. At the longer immersion time, GBR showed a reduction of $\gamma$-oryzanol content. The decrease of $\gamma$-oryzanol content in GBR var. Inpari 42, Inpari 43, and Inpari 17 was seen after soaked at 48 to $120 \mathrm{~h}$, while var. IPB $3 \mathrm{~S}$ was reported at 72 and $96 \mathrm{~h}$.

Changes of $\gamma$-oryzanol in brown rice during germination from our study were still unclear, even it typically decrease at the longer soaking time in several varieties. These are agreed with some research that have been previously reported. Some studies reported in decreasing $\gamma$-oryzanol content and some of them retaining or slight increasing. GBR from var. Indica SLF09 decreased by approximately 15\% after soaking for $24 \mathrm{~h}$ (Cáceres et al., 2017). The $\gamma$-oryzanol of five of eight brown rice varieties from South Sarawak, Malaysia also exhibited a slight decrease after germination by soaking for $24 \mathrm{~h}$ (Kiing et al., 2009). The Japanese brown rice (Koshihikari) soaked for $72 \mathrm{~h}$ at $30^{\circ} \mathrm{C}$ showed at the same level in $\gamma$-oryzanol content compared to the ungerminated brown rice (Ohtsubo et al., 2005). The study about germination in four Korean rice varieties (Ilpum, Gaomi2, Keunnun, and Heugkwang) reported that germinated brown rice var. Keunnun and Heugkwang had higher $\gamma$-oryzanol compared to the ungerminated brown rice, whereas the others remained unchanged (Lee et al., 2007).

\subsection{Fatty acid profiles of germinated brown rice}

The fatty acid composition was analyzed for ungerminated brown rice and selected GBR at $120 \mathrm{~h}$ germination (Table 2).

Table 1. The effect of germination on the $\gamma$-oryzanol content.

\begin{tabular}{|c|c|c|c|c|c|c|}
\hline \multirow{2}{*}{ Varieties } & \multicolumn{6}{|c|}{ Soaking times $(\mathrm{h})$} \\
\hline & 0 & 24 & 48 & 72 & 96 & 120 \\
\hline Inpari 42 & $41.89 \pm 0.87^{\mathrm{a}}$ & $41.98 \pm 0.71^{\mathrm{a}}$ & $38.53 \pm 0.39^{\mathrm{b}}$ & $37.33 \pm 0.58^{c}$ & $38.45 \pm 0.85^{\mathrm{b}}$ & $36.96 \pm 1.70^{c}$ \\
\hline Inpari 43 & $39.10 \pm 0.79^{b}$ & $40.58 \pm 1.07^{\mathrm{a}}$ & $37.37 \pm 2.09^{\mathrm{cd}}$ & $36.26 \pm 1.70^{\mathrm{d}}$ & $34.42 \pm 1.06^{\mathrm{e}}$ & $38.25 \pm 0.29^{\mathrm{bc}}$ \\
\hline Situ Bagendit & $57.62 \pm 2.72^{\mathrm{a}}$ & $49.95 \pm 2.27^{\mathrm{b}}$ & $47.70 \pm 0.44^{c}$ & $48.02 \pm 0.90^{c}$ & $45.09 \pm 1.01^{\mathrm{d}}$ & $47.71 \pm 2.05^{c}$ \\
\hline IPB 3S & $44.44 \pm 0.47^{\mathrm{a}}$ & $44.40 \pm 1.22^{\mathrm{a}}$ & $44.34 \pm 1.39^{\mathrm{a}}$ & $38.55 \pm 0.69^{\mathrm{b}}$ & $38.99 \pm 2.36^{\mathrm{b}}$ & $44.89 \pm 0.65^{\mathrm{a}}$ \\
\hline Inpari 17 & $47.81 \pm 1.21^{\mathrm{a}}$ & $48.05 \pm 1.49^{\mathrm{a}}$ & $43.66 \pm 1.65^{b c}$ & $42.92 \pm 1.11^{\mathrm{c}}$ & $43.49 \pm 1.69^{b c}$ & $44.92 \pm 1.91^{\mathrm{b}}$ \\
\hline
\end{tabular}

Note: Values with different letters in the same row are significantly different $(\mathrm{p}<0.05)$. 
Table 2. Fatty acid compositions of brown rice and germinated brown rice.

\begin{tabular}{|c|c|c|c|c|c|c|c|c|c|c|}
\hline \multirow{2}{*}{ Fatty acids } & \multicolumn{2}{|c|}{ Inpari 42} & \multicolumn{2}{|c|}{ Inpari 43} & \multicolumn{2}{|c|}{ Situ Bagendit } & \multicolumn{2}{|c|}{ IPB 3S } & \multicolumn{2}{|c|}{ Inpari 17} \\
\hline & $\mathrm{BR}$ & GBR & $\mathrm{BR}$ & GBR & $\mathrm{BR}$ & GBR & $\mathrm{BR}$ & GBR & $\mathrm{BR}$ & GBR \\
\hline C14:0 & 0.57 & 0.82 & 0.67 & 0.73 & 0.56 & 0.70 & 0.74 & 0.97 & 0.75 & 0.58 \\
\hline $\mathrm{C} 16: 0$ & 18.31 & 17.98 & 18.85 & 17.51 & 17.51 & 17.25 & 18.37 & 19.25 & 18.25 & 18.19 \\
\hline C16:1 & 0.20 & 0.23 & 0.19 & 0.18 & 0.17 & 0.21 & 0.17 & 0.17 & 0.21 & 0.19 \\
\hline C18:0 & 1.62 & 1.74 & 1.75 & 1.65 & 1.61 & 1.74 & 1.73 & 1.79 & 1.64 & 1.91 \\
\hline $\mathrm{C} 18: 1$ cis & 35.92 & 36.00 & 35.86 & 34.41 & 34.60 & 35.36 & 34.39 & 33.63 & 35.83 & 34.36 \\
\hline C18:2 & 40.32 & 40.12 & 38.88 & 40.52 & 40.90 & 41.34 & 41.19 & 39.62 & 40.26 & 41.56 \\
\hline $\mathrm{C} 18: 3$ & 2.02 & 2.03 & 2.36 & 2.88 & 2.66 & 2.31 & 2.34 & 2.84 & 2.00 & 2.08 \\
\hline C20:0 & 0.29 & 0.30 & 0.37 & 0.36 & 0.36 & 0.36 & 0.29 & 0.30 & 0.29 & 0.38 \\
\hline C20:1 & 0.41 & 0.47 & 0.56 & 1.18 & 1.00 & 0.44 & 0.46 & 0.88 & 0.42 & 0.41 \\
\hline C22:0 & 0.34 & 0.31 & 0.50 & 0.57 & 0.62 & 0.29 & 0.32 & 0.56 & 0.34 & 0.36 \\
\hline SFA & 21.13 & 21.15 & 22.14 & 20.82 & 20.67 & 20.34 & 21.45 & 22.86 & 21.28 & 21.41 \\
\hline USFA & 78.87 & 78.85 & 77.86 & 79.18 & 79.33 & 79.66 & 78.55 & 77.14 & 78.72 & 78.59 \\
\hline TFA & 100 & 100 & 100 & 100 & 100 & 100 & 100 & 100 & 100 & 100 \\
\hline
\end{tabular}

Note: $\mathrm{BR}=$ Brown rice; GBR = Germinated brown rice (at $120 \mathrm{~h}$ ); SFA = Saturated fatty acids; USFA = Unsaturated fatty acids; TFA = Total fatty acids. All numbers are presented in $\%$ (mg/100 mg total fatty acid).

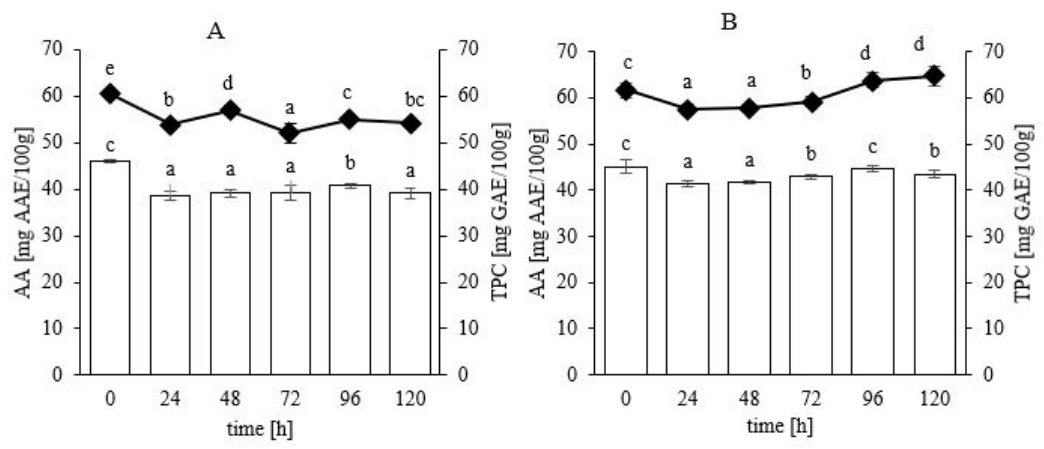

C

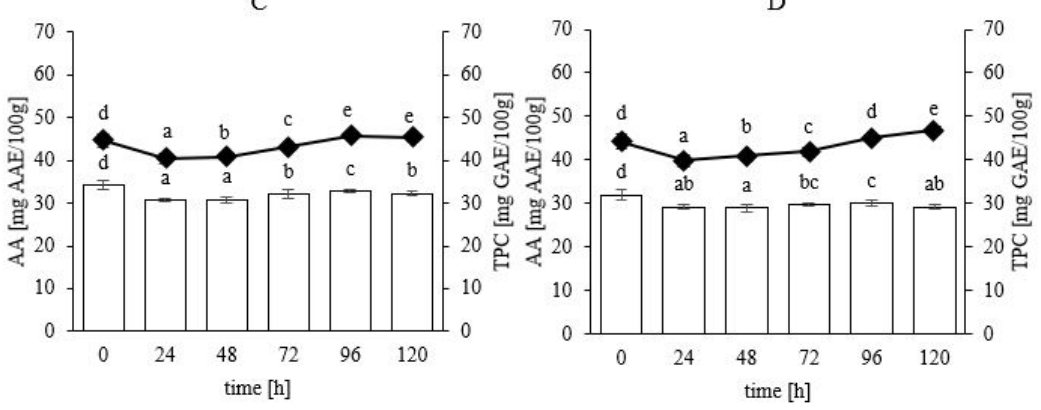

$\mathrm{E}$

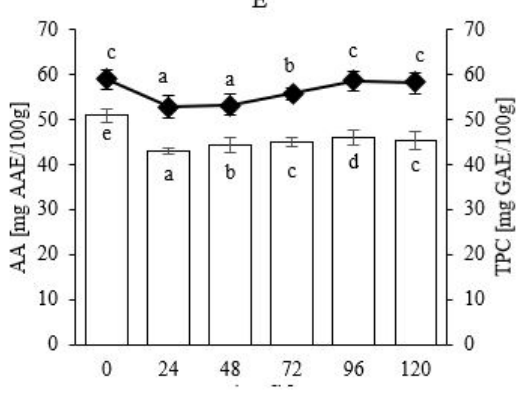

Figure 2. Total phenolic content (TPC) and antioxidant activity (AA) of germinated brown rice from five Indonesian rice varieties (bar chart for DPPH scavenging activity; line chart for TPC). (A) Inpari 42; (B) Inpari 43; (C) Situ Bagendit; (D) IPB 3S; (E) Inpari 17. Different letters indicate values are significantly different $(\mathrm{p}<0.05)$. 
The germination process did not affect the composition of fatty acids as indicated by the identical fatty acids compositions in ungerminated brown rice and GBR. Both in ungerminated brown rice and GBR $120 \mathrm{~h}$, the composition of fatty acids was dominated by palmitic acid (C16:0), oleic acid (C18:1), and linoleic acid (C18:2), which contributed to $17-19 \%, 33-36 \%$, and $38-41 \%$ of the fatty acid composition, respectively. The remaining minor compounds of fatty acids consisted of myristic (C14:0), palmitoleic (C16:1), stearic (C18:0), linolenic (C18:3), arachidic acid (C20:0), cis-11 eicosenoic (C20:1), docosanoic acid (C22:0). Based on its saturation, both ungerminated brown rice and GBR were dominated by unsaturated fatty acids that contributed to $77-79 \%$ of total fatty acid content, whereas saturated fatty acids only contributed approximately $21-23 \%$. These results were comparable in brown rice var. IR 64 and BPT that reported no obvious changes in fatty acid compositions after germination (Jayadeep \& Malleshi, 2011).

\subsection{The effect of germination on pasting profiles of germinated brown rice}

The pasting profiles of five Indonesian brown rice varieties during germination was presented in Figure 3. The germination process significantly modified the pasting profiles of brown rice for all rice varieties. In this study, germination of brown rice by the soaking method considerably impact the reduction of peak viscosity, trough viscosity, breakdown, setback, and final viscosity. The lower peak viscosity occurred especially after soaking for $48 \mathrm{~h}$ or longer.
A
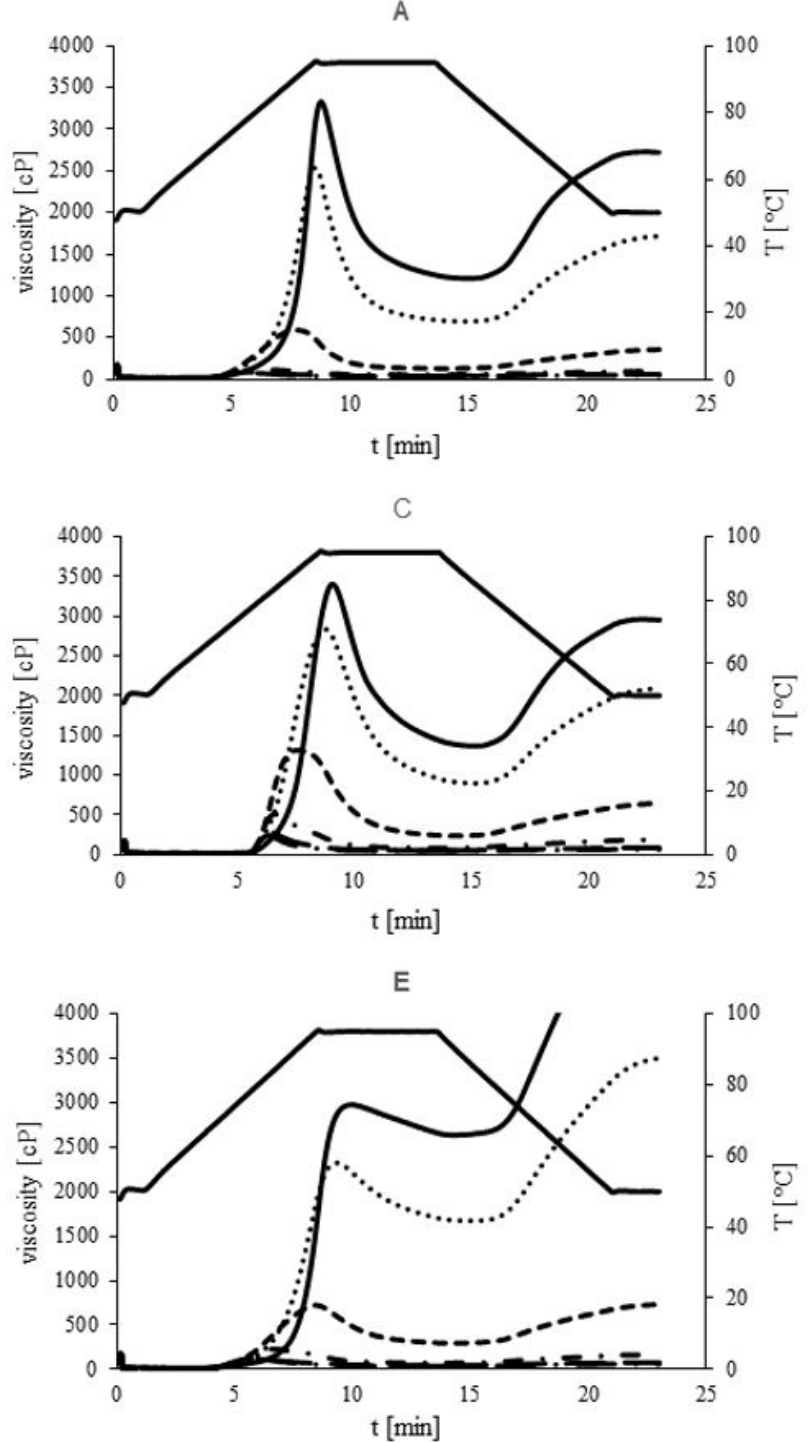

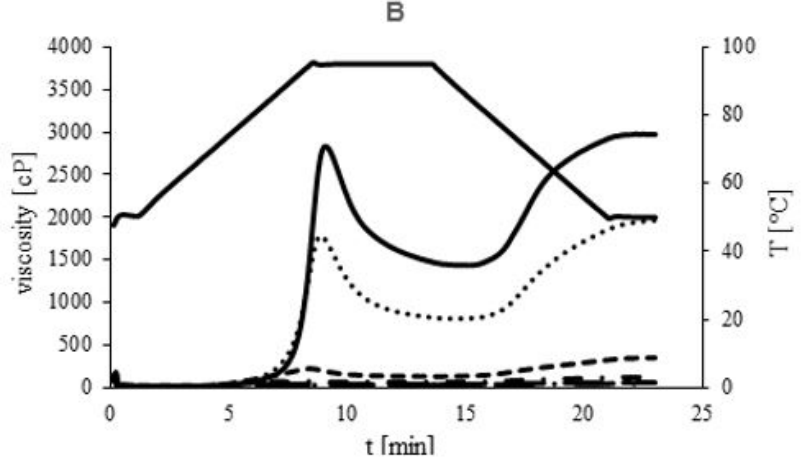

D

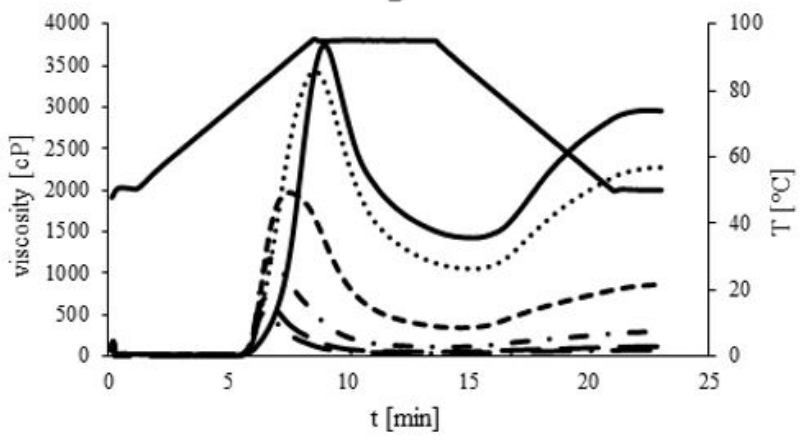

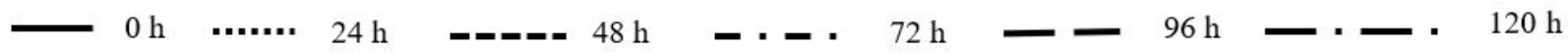

Figure 3. Pasting properties changes of brown rice and germinated brown rice: (A) Inpari 42; (B) Inpari 43; (C) Situ Bagendit; (D) IPB 3S; (E) Inpari 17. 
The pasting behavior of food materials during the heating and cooling process influences the quality of final products (Xu et al., 2012). The GBR in all varieties experienced the decline of peak viscosity, trough viscosity, breakdown, setback, and final viscosity. The decrease of peak viscosity was attributed to the presence of endogenous hydrolytic enzymes activity such as amylase enzyme, which hydrolyzed starch to smaller molecules (Wichamanee \& Teerarat, 2012). It is well documented in the previous study that $\alpha$-amylase, as well as $\beta$-amylase enzymes, increased as germination progressing, thus, leading to a decrease in peak viscosity (Mohan et al., 2010; Pinkaew et al., 2016). Germination also reduced trough and breakdown viscosity which related to the stability of the flour during the heating process (Mohan et al., 2010). After heating at a particular time, the pasting flour was then cooled down to obtain the final viscosity and setback value. The setback and final viscosity usually represent the retrogradation tendency. In this study, the reduction of setback value indicates that GBR is more stable against retrogradation.

\section{Conclusion}

The germination process from five Indonesian rice varieties by a full soaking method, was found to significantly increase the GABA content of all Indonesian varieties used in this study. The highest GABA content was obtained in GBR var. Inpari 43 which increased consistently up to 4.7 -fold after soaking $120 \mathrm{~h}$. TPC, antioxidant activity, and $\gamma$-oryzanol contents did not increase after germination, as well as fatty acid compositions. Germination influenced the pasting profiles of GBR. The longer period of soaking time caused the lower peak viscosity, breakdown, and setback value. Based on this, GBR was less viscous and more stable during heating and cooling.

\section{References}

Bligh, E. G., \& Dyer, W. J. (1959). A rapid method of total lipid extraction and purification. Canadian Journal of Biochemistry and Physiology, 37(8), 911-917. http://dx.doi.org/10.1139/o59-099. PMid:13671378.

Brand-Williams, W., Cuvelier, M. E., \& Berset, C. (1995). Use of a free radical method to evaluate antioxidant activity. LebensmittelWissenschaft + Technologie, 28(1), 25-30. http://dx.doi.org/10.1016/ S0023-6438(95)80008-5.

Cáceres, P. J., Martínez-Villaluenga, C., Amigo, L., \& Frias, J. (2014). Maximising the phytochemical content and antioxidant activity of Ecuadorian brown rice sprouts through optimal germination conditions. Food Chemistry, 152, 407-414. http://dx.doi.org/10.1016/j. foodchem.2013.11.156. PMid:24444955.

Cáceres, P. J., Peñas, E., Martinez-Villaluenga, C., Amigo, L., \& Frias, J. (2017). Enhancement of biologically active compounds in germinated brown rice and the effect of sun-drying. Journal of Cereal Science, 73, 1-9. http://dx.doi.org/10.1016/j.jcs.2016.11.001.

Cho, D. H., \& Lim, S. T. (2016). Germinated brown rice and its biofunctional compounds. Food Chemistry, 196, 259-271. http://dx.doi. org/10.1016/j.foodchem.2015.09.025. PMid:26593491.

Gong, E. S., Luo, S. J., Li, T., Liu, C. M., Zhang, G. W., Chen, J., Zeng, Z. C., \& Liu, R. H. (2017). Phytochemical profiles and antioxidant activity of brown rice varieties. Food Chemistry, 227, 432-443. http://dx.doi.org/10.1016/j.foodchem.2017.01.093. PMid:28274454.
Jayadeep, A., \& Malleshi, N. G. (2011). Nutrients, composition of tocotrienols, tocopherols, and c-oryzanol, and antioxidant activity in brown rice before and after biotransformation. CYTA: Journal of Food, 9(1), 82-87. http://dx.doi.org/10.1080/19476331003686866.

Kaosa-ard, T., \& Songsermpong, S. (2012). Influence of germination time on the GABA content and physical properties of germinated brown rice. Asian Journal of Food and Agro-Industry, 5(04), 270-283.

Kaur, M., Asthir, B., \& Mahajan, G. (2017). Variation in antioxidants, bioactive compounds and antioxidant capacity in germinated and ungerminated grains of ten rice cultivars. Rice Science, 24(6), 349359. http://dx.doi.org/10.1016/j.rsci.2017.08.002.

Kiing, S. C., Yiu, P. H., Rajan, A., \& Wong, S. C. (2009). Effect of germination on $\gamma$-oryzanol content of selected sarawak rice cultivars. American Journal of Applied Sciences, 6(9), 1658-1661. http://dx.doi. org/10.3844/ajassp.2009.1658.1661.

Lee, Y. R., Kim, J. Y., Woo, K. S., Hwang, I. G., Kim, K. H., Kim, K. J., \& Jeong, H. S. (2007). Changes in the chemical and functional components of Korean rough rice before and after germination. Food Science and Biotechnology, 16, 1006-1010.

Lilitchan, S., Tangprawat, C., Aryusuk, K., Krisnangkura, S., Chokmoh, S., \& Krisnangkura, K. (2008). Partial extraction method for the rapid analysis of total lipids and $\gamma$-oryzanol contents in rice bran. Food Chemistry, 106(2), 752-759. http://dx.doi.org/10.1016/j. foodchem.2007.06.052.

Mohan, B., Malleshi, N. G., \& Koseki, T. (2010). Physico-chemical characteristics and non-starch polysaccharide contents of Indica and Japonica brown rice and their malts. Lebensmittel-Wissenschaft + Technologie, 43(5), 784-791. http://dx.doi.org/10.1016/j.lwt.2010.01.002.

Munarko, H., Sitanggang, A. B., Kusnandar, F., \& Budijanto, S. (2019). Germinated brown rice: Production process and its characteristics. Pangan, 28(3), 239-252.

Munarko, H., Sitanggang, A. B., Kusnandar, F., \& Budijanto, S. (2020). Phytochemical, fatty acid and proximal composition of six selected Indonesian brown rice varieties. CYTA: Journal of Food, 18(1), 336343. http://dx.doi.org/10.1080/19476337.2020.1754295.

Ohtsubo, K., Suzuki, K., Yasui, Y., \& Kasumi, T. (2005). Bio-functional components in the processed pre-germinated brown rice by a twinscrew extruder. Journal of Food Composition and Analysis, 18(4), 303-316. http://dx.doi.org/10.1016/j.jfca.2004.10.003.

Phattayakorn, K., Pajanyor, P., Wongtecha, S., Prommakool, A., \& Saveboworn, W. (2016). Effect of germination on total phenolic content and antioxidant properties of "Hang" rice. International Food Research Journal, 23(1), 406-409.

Pinkaew, H., Thongngam, M., Wang, Y. J., \& Naivikul, O. (2016). Isolated rice starch fine structures and pasting properties changes during pre-germination of three Thai paddy (Oryza sativa L.) cultivars. Journal of Cereal Science, 70, 116-122. http://dx.doi.org/10.1016/j. jcs.2016.05.009.

Shelp, B. J., Bown, A. W., \& McLean, M. D. (1999). Metabolism and functions of gamma- aminobutyric acid. Trends in Plant Science, 4(11), 446-451. http://dx.doi.org/10.1016/S1360-1385(99)01486-7. PMid:10529826.

Taufik, M., Lioe, H. N., \& Yuliana, N. D. (2016). Evaluation of major fatty acids determination in palm oil by Gas Chromatography-Flame Ionization Detection. Jurnal Agritech, 36(03), 308-316. http://dx.doi. org/10.22146/agritech.16603.

Thitinunsomboon, S., Keeratipibul, S., \& Boonsiriwit, A. (2013). Enhancing gamma-aminobutyric acid content in germinated brown rice by repeated treatment of soaking and incubation. Food 
Science \& Technology International, 19(1), 25-33. http://dx.doi. org/10.1177/1082013212442180. PMid:23345323.

Tiansawang, K., Luangpituksa, P., Varanyanond, W., \& Hansawasdi, C. (2016). GABA ( $\gamma$-aminobutyric acid) production, antioxidant activity in some germinated dietary seeds and the effect of cooking on their GABA content. Food Science and Technology, 36(2), 313321. http://dx.doi.org/10.1590/1678-457X.0080.

Watchararparpaiboon, W., Laohakunjit, N., \& Kerdchoechuen, O. (2010). An improved process for high quality and nutrition of brown rice production. Food Science \& Technology International, 16(2), 147158. http://dx.doi.org/10.1177/1082013209353220. PMid:21339130.

Wichamanee, Y., \& Teerarat, I. (2012). Production of germinated red jasmine brown rice and its physicochemical properties. International Food Research Journal, 19(4), 1649-1654.
Xia, Q., Mei, J., Yu, W., \& Li, Y. (2017). High hydrostatic pressure treatments enhance volatile components of pre-germinated brown rice revealed by aromatic fingerprinting based on HS-SPME/GC-MS and chemometric methods. Food Research International, 91, 103-114. http://dx.doi.org/10.1016/j.foodres.2016.12.001. PMid:28290313.

Xu, J., Zhang, H., Guo, X., \& Qian, H. (2012). The impact of germination on the characteristics of brown rice flour and starch. Journal of the Science of Food and Agriculture, 92(2), 380-387. http://dx.doi. org/10.1002/jsfa.4588. PMid:21968914.

Zhang, Q., Xiang, J., Zhang, L., Zhu, X., Evers, J., van der Werf, W., \& Duan, L. (2014). Optimizing soaking and germination conditions to improve gamma-aminobutyric acid content in japonica and indica germinated brown rice. Journal of Functional Foods, 10, 283-291. http://dx.doi.org/10.1016/j.jff.2014.06.009. 